\title{
Effect of Cell Length on Performance and Transport Phenomena in Solid Oxide Fuel Cells
}

\author{
Qiuwan Shen ${ }^{1}$, Shian Li ${ }^{1}$, Guogang Yang ${ }^{1, *}$, Naibao Huang ${ }^{2, *}$ \\ ${ }^{1}$ Marine Engineering College, Dalian Maritime University, Dalian, China; \\ ${ }^{2}$ Transportation Equipment and Ocean Engineering College, Dalian Maritime University, Dalian, \\ China; \\ *E-mail: yanggg@dlmu.edu.cn and nbhuang@ dlmu.edu.cn
}

doi: $10.20964 / 2019.06 .66$

Received: 11 February 2019 / Accepted: 5 April 2019 / Published: 10 May 2019

\begin{abstract}
In the present study, the overall cell performance and local transport characteristics of anode-supported solid oxide fuel cells (SOFCs) are numerically investigated by using a two-dimensional mathematical model. The conservation equations of mass, momentum, species, energy and charge are solved to describe the transport processes in fuel cells. The model validation has been performed by comparing the numerical results with experimental data found in the open literature. Effects of cell length and flow direction arrangement on temperature and species distributions are systematically investigated. It is concluded that the performance of SOFCs is significantly increased when the cell length is increased. In addition, the temperature and species distributions are also greatly affected by the cell length and flow direction arrangement.
\end{abstract}

Keywords: Solid oxide fuel cells, Modeling, Cell length, Flow arrangement

\section{FULL TEXT}

(C) 2019 The Authors. Published by ESG (www.electrochemsci.org). This article is an open access article distributed under the terms and conditions of the Creative Commons Attribution license (http://creativecommons.org/licenses/by/4.0/). 